\title{
Predation on myctophids by the squid Moroteuthis ingens around Macquarie and Heard Islands: stomach contents and fatty acid analyses
}

\author{
Katrina L. Phillips ${ }^{1, *}$, George D. Jackson ${ }^{1}$, Peter D. Nichols ${ }^{2,3}$ \\ ${ }^{1}$ Institute of Antarctic and Southern Ocean Studies, University of Tasmania, GPO Box 252-77, Hobart, \\ Tasmania 7001, Australia \\ ${ }^{2}$ CSIRO Division of Marine Research, GPO Box 1538, Hobart, Tasmania 7001, Australia \\ ${ }^{3}$ Antarctic CRC, University of Tasmania, GPO Box 252-80, Hobart, Tasmania 7001, Australia
}

\begin{abstract}
The diet of the sub-Antarctic onychoteuthid squid Moroteuthis ingens was assessed using stomach contents analyses and fatty acids as dietary tracers. The contents of 54 stomachs (50 from squid collected near Macquarie Island and 4 from squid collected near Heard Island) were examined visually, and prey remains were identified to species level where possible. Myctophid fish were the most common prey item in the stomach contents of $M$. ingens and were identified in $59 \%$ of stomachs. In total, teleost fish remains were found in $96 \%$ of stomachs. The lipid class and fatty acid profiles of the digestive gland and mantle tissue were analysed for 5 to 6 squid from each area, in addition to 4 stomach fluid samples taken from Heard Island animals. Mantle tissue was low in lipid, and contained high concentrations of phospholipids and polyunsaturated fatty acids. Digestive gland tissue had a high lipid content, with a mean value of $26.8 \pm 12.9 \%$ wet mass in Macquarie Island squid and $41.7 \pm 8.5 \%$ wet mass in Heard Island squid, and was rich in triacylglycerol (TAG) and monounsaturated fatty acids (MUFA). Stomach fluid generally contained high concentrations of TAG, although 1 sample was high in wax ester. Stomach fluid was also characterised by high MUFA concentrations. The digestive gland of $M$. ingens grouped with the fatty acid profile of stomach fluid and some myctophid species in cluster analysis and multidimensional scaling, and appears to be a source of fatty acid dietary tracers. Thus the fatty acid profile of the digestive gland supports findings from stomach contents analyses that myctophids, particularly TAG-rich species, are an important prey group of $M$. ingens at Macquarie and Heard Islands. This combination of techniques has a potential to increase our knowledge of the feeding ecology of squids in the Southern Ocean.
\end{abstract}

KEY WORDS: Squid · Lipid · Digestive gland · Diet · triacylglycerol $\cdot$ Monounsaturated fatty acids · Southern Ocean

Resale or republication not permitted without written consent of the publisher

\section{INTRODUCTION}

The onychoteuthid squid Moroteuthis ingens is one of the most abundant and ecologically important squid species found in the sub-Antarctic Southern Ocean. It is a major prey item for many species of seabird, fish and marine mammals (Green \& Burton 1993, Clarke \&

*E-mail: katrina@postoffice.antcrc.utas.edu.au
Goodall 1994, Cherel et al. 1996, Clarke \& Roeleveld 1998, Jackson et al. 1998a, Jackson et al. 2000). It is also thought to play a role in the transfer of energy from the pelagic to the demersal environment due to the ontogenetic migration of mature females to depths greater than $700 \mathrm{~m}$ (Jackson 1993). M. ingens is a voracious feeder that potentially consumes in excess of $10 \%$ of its body weight $\mathrm{d}^{-1}$ (Jackson et al. 1998b); therefore, it has a significant impact on the ecosystem as a predator. 
Although there has been no commercial interest in this species, Moroteuthis ingens is taken as by-catch by a number of fishing operations, notably from the Patagonian toothfish (Dissostichus eleginoides) fishery concentrated around Macquarie Island and around Heard Island and McDonald Island in the CCAMLR (Convention for the Conservation of Antarctic Marine Living Resources) Sector 58.5.2. Because of the dependence of a number of vertebrate predators on $M$. ingens and the impact that it has on its prey populations, it is important to obtain more information on the trophic interactions of this species. This will allow for the construction of appropriate ecosystem models and the implementation of management strategies in these areas that are vulnerable to fisheries exploitation. This study was focused on undertaking a preliminary assessment of the feeding ecology of $M$. ingens at Macquarie and Heard islands.

Dietary studies of oceanic squids have been restricted mostly to conventional stomach contents analyses. However, many sources of bias are associated with these studies, which have been discussed elsewhere (Lipinski 1987, Kear 1992, Rodhouse \& Nigmatullin 1996, Dawe et al. 1997, Jackson et al. 1998b, Lordan et al. 1998). As a result, Kear (1992) warns against using conventional stomach contents analyses in isolation to determine important prey items. This study used a combination of techniques to determine the diet of Moroteuthis ingens at Macquarie and Heard islands: stomach content analyses and fatty acids as dietary tracers.

Fatty acids have shown potential as dietary tracers in marine trophic systems, particularly if passed unmodified from prey to predator. Many novel fatty acids exist in the marine environment, which can only be biosynthesised by certain phytoplankton and seaweed species (Sargent 1976, Ackman 1980) and become essential dietary components to higher trophic levels. Long-chain polyunsaturated fatty acids (PUFA) are primary examples of such essential dietary components.

While the metabolism of squid is thought to be largely protein-based with most tissues low in lipid, the digestive gland (DG) of some squid species is lipid rich (Hayashi \& Yamamoto 1987a, Hayashi et al. 1990). The role of the DG in lipid regulation is unclear. However, Semmens (1998) has suggested that it stores lipid before excretion, while Clarke et al. (1979) suggests that high lipid concentrations may assist with the maintenance of neutral buoyancy. In either scenario, fatty acids stored in the DG are unlikely to have been modified from the diet as squid have a limited capacity to catabolise lipid (Vonk 1962, Ballantyne et al. 1981, Mommsen \& Hochachka 1981).

Thus, the DG is a potential source of dietary fatty acids and may be a useful tool in future studies of the feeding ecology of squids when used in combination with stomach contents analyses.

\section{MATERIALS AND METHODS}

Sample description and preparation. Eighty-two individuals of Moroteuthis ingens (51 female and 31 male) were collected from commercial fishing vessels by Australian Fisheries Management Authority observers from 2 geographically distant localities in the Southern Ocean. During the periods December 1997 to January 1998 and October 1998 to January 1999, 74 squid were collected near Macquarie Island (Pacific Ocean Sector) between $158^{\circ} 50^{\prime} \mathrm{E}, 52^{\circ} 22^{\prime} \mathrm{S}$ and $158^{\circ} 23^{\prime} \mathrm{E}, 55^{\circ} 23^{\prime} \mathrm{S}$ in 500 to $1198 \mathrm{~m}$ depth. Eight individual were collected during March and April 1999 near Heard and McDonald islands (Indian Ocean Sector), between $74^{\circ} 17^{\prime} \mathrm{E}, 50^{\circ} 45^{\prime} \mathrm{S}$ and $74^{\circ} 47^{\prime} \mathrm{E}, 52^{\circ} 55^{\prime} \mathrm{S}$ in 500 to $600 \mathrm{~m}$ depth. All squid were frozen on board and returned to Hobart for analysis. Individuals were allocated a maturation stage according to a subjective 5-point scale (after Lipinski 1979).

Stomach contents analyses. Intact stomachs were collected from 54 individual animals; stomachs that had been badly damaged were discarded. Fullness of intact stomachs was determined on a 6-point subjective scale (after Zuev et al. 1985, Jackson et al. 1998b). Stomachs were weighed, and a small fluid portion (containing no hard parts) was drained from stomachs collected from Heard Island and retained for lipid and fatty acid analysis. The contents were then rinsed in a $500 \mu \mathrm{m}$ mesh sieve and sorted in a Petri dish under a dissection microscope. The state of digestion was determined on a 6-point subjective scale (after Zuev et al. 1985).

Sagittal otoliths were removed, dried and stored in small plastic bags before identification to species level where possible (Williams \& McEldowney 1990). Squid beaks were stored dry in plastic vials, while gladii and intact tissue pieces were preserved in $75 \%$ ethanol. Statoliths were stored dry in small plastic bags. No attempt was made to identify squid remains. Crustaceans were stored in $75 \%$ ethanol and were identified to genus and, where possible, species level (Hosie \& Kitchener pers. comm.).

Lipid extraction and fatty acid analysis. Whole DGs and a small mantle tissue sample (taken from the ventral mantle) were retained for lipid and fatty acid analysis. These were stored frozen at $-20^{\circ} \mathrm{C}$ along with the stomach fluid samples collected from Heard Island animals. Six DGs, 6 mantle samples and 4 stomach fluid samples from Heard Island were selected for analysis, and 5 DG and 6 mantle samples were analysed from Macquarie Island. Entire DGs were ground up in a mortar and pestle, and a $1 \mathrm{~g}$ subsample was taken for lipid extraction. Mantle tissue samples weighing $1 \mathrm{~g}$ were ground in a mortar and pestle before extraction, and a $1 \mathrm{~g}$ portion was 
taken from each stomach fluid sample for lipid extraction.

All tissue samples were extracted overnight using a method modified from Bligh \& Dyer (1959) in a 1-phase methanol:chloroform:water solvent mixture $(2: 1: 0.8$ $\mathrm{v} / \mathrm{v} / \mathrm{v})$. Phases were separated the following day by addition of chloroform and water (final solvent ratio, 1:1:0.9 v/v/v methanol:chloroform:water). Lipids were recovered in the lower chloroform phase, and the solvent was removed under vacuum to give the total solvent extract; these were weighed to obtain total lipid content (percentage wet mass). All samples were made up to a known volume in chloroform and stored at $-20^{\circ} \mathrm{C}$. An aliquot of the total solvent extract was analysed with an Iatroscan MK V TH10 TLC flame ionisation detector (Iatrosan Laboratories, Chiyoda-ku, Japan) to determine the proportion of major lipid classes. A polar solvent system (60:17:0.1 v/v/v ratio of hexane:ether:acetic acid) was used to resolve triacylglycerols (TAG), free fatty acids, sterols and phospholipids, while a non-polar solvent system $(96: 4 \mathrm{v} / \mathrm{v}$ ratio of hexane:ether) was used to determine diacylglyceryl ethers and wax esters. Peaks were quantified with DAPA Scientific Software (Kalamunda, Western Australia).

An aliquot of the total solvent extract was transmethylated at $80^{\circ} \mathrm{C}$ for $2 \mathrm{~h}$ in a 10:1:1 v/v/v mixture of methanol:hydrochloric acid:chloroform to produce fatty acid methyl esters. Fatty acid methyl esters were partitioned by the addition of water and extracted with 4:1 hexane:chloroform v/v under nitrogen, then silylated at $60^{\circ} \mathrm{C}$ overnight in N,O-bis-(trimethylsilyl)trifluoracetamide (Nichols et al. 1994). Fatty acid methyl esters were then reduced under nitrogen and stored in chloroform at $-20^{\circ} \mathrm{C}$. Fatty acid components were determined by gas chromatography using a Hewlett Packard (PA, USA) 5890A gas chromatograph equipped with an HP-5 cross-linked methyl silicone fused capillary column, flame ionisation detector, a split/splitless injector and an HP 7673A auto sampler. Component identification was confirmed by GC-MS analysis using a Finnigan Thermoquest GCQ GC-MS (CA, USA) fitted with an on-column injector. Peaks were quantified with Waters Millennium software (Milford, MA, USA).

Statistical analyses. Two-tailed $t$-tests assuming unequal variance were used to determine significant differences within a $95 \%$ CI. Fatty acid profiles were compared by cluster analysis using Pearson's correlation coefficient and average linkage. Pearson's correlation coefficient and non-metric multidimensional scaling (MDS) were also used to compare fatty acid profiles in 2 dimensions, using the Kruskal Loss Function. All multivariate analyses were conducted using SYSTAT 9 (SYSTAT, Inc, Evanston, IL, USA).

\section{RESULTS}

\section{General biology}

Female squid were significantly larger in mantle length $(\mathrm{ML})(\mathrm{p}<0.02$, mean $\mathrm{ML}=286 \mathrm{~mm}$, maximal $\mathrm{ML}=432 \mathrm{~mm})$ and total mass $(\mathrm{TM})(\mathrm{p}<0.005$, mean $\mathrm{TM}=783 \mathrm{~g}$, maximal $\mathrm{TM}=2613 \mathrm{~g}$ ) than males (mean $\mathrm{ML}=257 \mathrm{~mm}$, maximal $\mathrm{ML}=360 \mathrm{~mm}$; mean $\mathrm{TM}=538 \mathrm{~g}$, maximal $\mathrm{TM}=1436 \mathrm{~g}$ ). A positive relation existed between ML and TM for both females and males (Fig. 1). Most males were fully mature, with only 7 specimens in various stages of immaturity. Conversely, no females were mature. Nidamental glands were small and undeveloped, and oviducts and oviducal glands were very small and transparent. There was a positive relation between TM and DG mass (Fig. 2a), and between ML and DG mass (Fig. 2b).

\section{Stomach contents}

Ingested food was determined to accumulate in the stomach of Moroteuthis ingens, previously described as the caecum by Jackson et al. (1998b). The spiral caecum is small and lacks a caecal sac in this species. Most stomachs were only moderately full with a fullness score of 1 to 3 (Table 1). Some stomachs contained large amounts of tissue and bone but no or few otoliths or eye lenses, which suggests that the heads of the fish

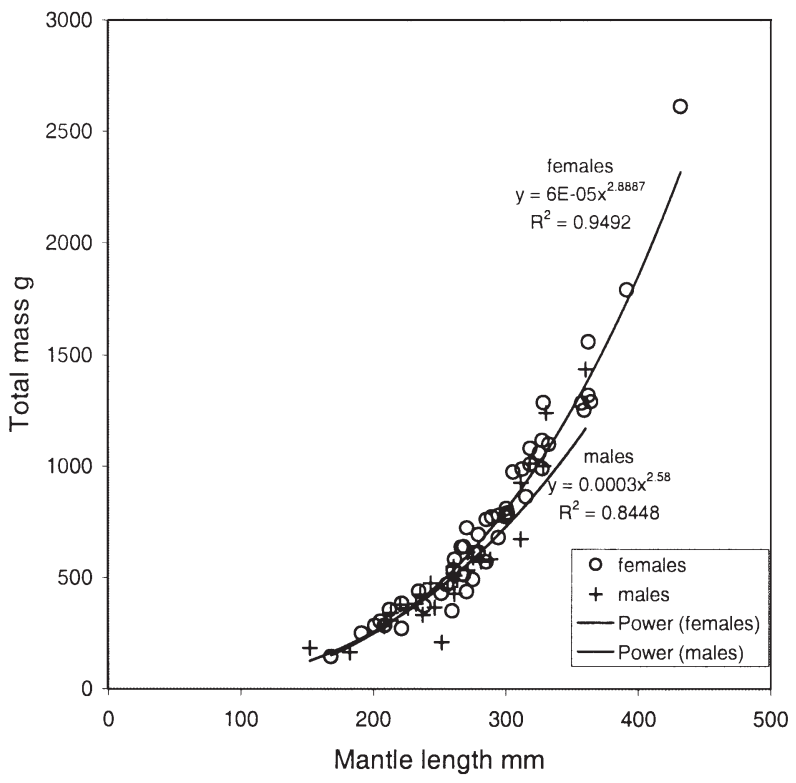

Fig. 1. Mantle length (mm) versus total mass (g) for Moroteuthis ingens. A positive relation is observed between total mass and mantle length for both male and female squid, although female squid reach a larger size 
Table 1. Fullness and digestion stages of stomachs collected from Moroteuthis ingens. na: not applicable

\begin{tabular}{|lrrrrr|r|}
\hline Digestion/fullness stage & 1 & 2 & 3 & 4 & 5 \\
\hline No. of stomachs at each fullness stage & 15 & 11 & 19 & 7 & 3 \\
No. of stomachs at each digestion stage & 0 & 0 & 14 & 28 & 10 \\
\end{tabular}
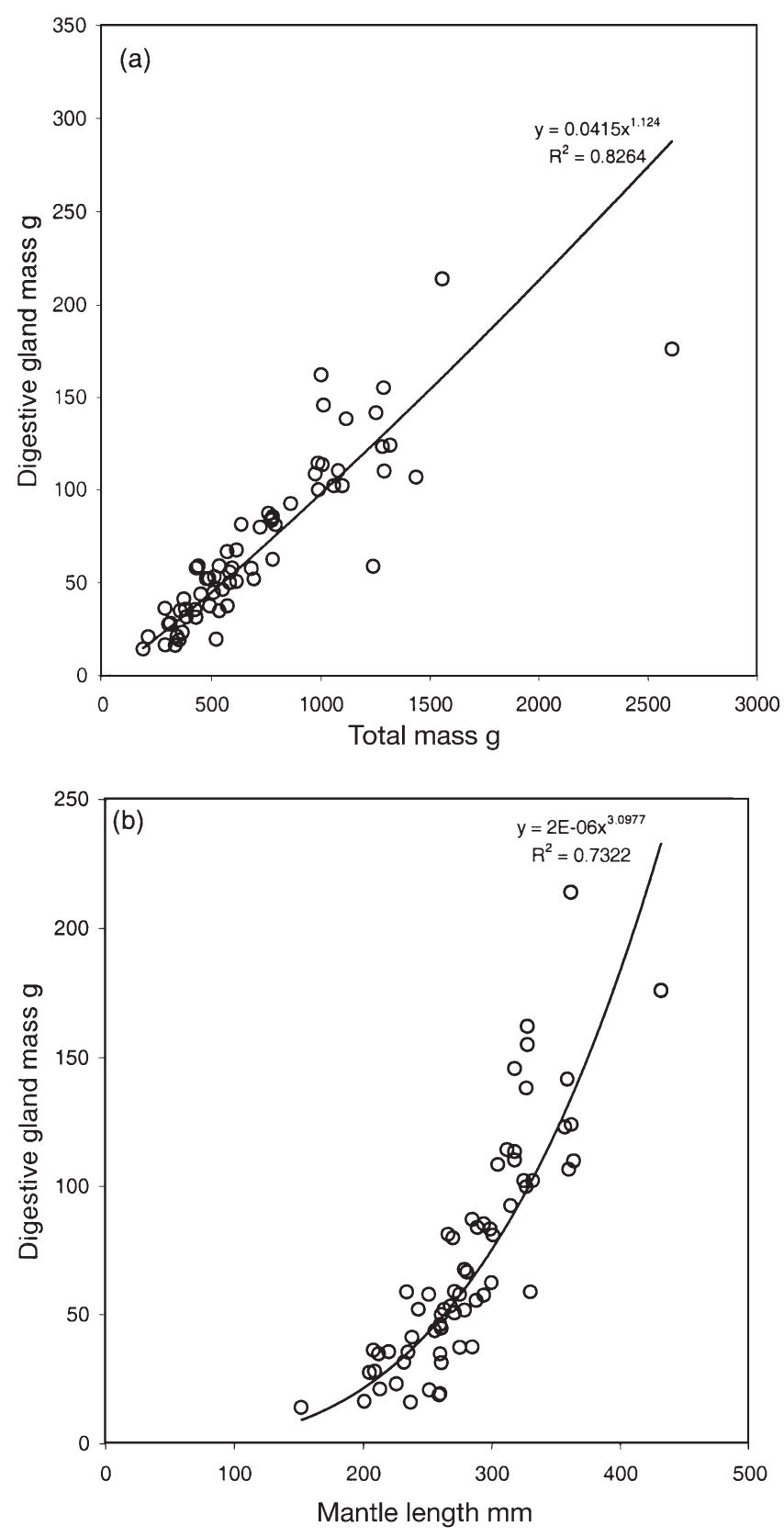

Fig. 2. (a) Total mass (g) versus digestive gland mass ( $g$ ) for Moroteuthis ingens. (b) Mantle length (mm) versus digestive gland mass $(\mathrm{g})$ for $M$. ingens. A positive relation is observed between digestive gland mass and total mass, and between digestive gland mass and mantle length prey had not been consumed. However, some stomachs contained large numbers of otoliths. Two females contained 75 and 76 otoliths from at least 38 fish, while 1 male contained 55 otoliths from at least 27 fish. These data suggest large consumption rates by individual squid. All stomach contents were in a moderate to high state of digestion, with no pieces of intact tissue available for prey identification (Table 1). Most tissue was in an amorphous condition, while most hard parts (bones, scales, otoliths, gladii and beaks) were clean of tissue, thin and eroded. As a result, no attempt was made to measure otoliths to obtain standard length or wet mass of fish prey.

Myctophid fish were the most common prey item identified in stomach contents $(59 \%$ frequency of occurrence). At least 12 myctophid species were identified in the prey spectrum; some myctophid otoliths (e.g., Protomyctophum sp.) could not be identified to species level. In total, bony fish remains were found in $96 \%$ of stomachs (Table 2) and appear to be the major prey of Moroteuthis ingens at Macquarie and Heard islands based on stomach contents data. Other fish species identified from otoliths belonged to the Bathylagidae family (Bathylagus antarcticus) and Paralepididae family (Magnisudis prinosa). Protomyctophum sp., B. antarcticus and Gymnoscopelus braueri were found in the greatest number of stomachs (frequency occurrence of 21, 19 and 19\% respectively), whereas the largest number of otoliths belonged to Gymnoscopelus sp., Krefftichthys anderssoni and Electrona subaspera (n = 85, 69 and 55 respectively) (Table 2).

Squid remains were found in $47 \%$ of stomachs; however, these rarely contributed to the bulk of material in the stomach and only 2 stomachs contained squid remains alone. Most squid beaks were deformed and not intact. In addition, very few lower beaks were found, precluding the identification of remains. Crustacean prey was found in $9 \%$ of stomachs, consisting of small amphipods and copepods. Crustaceans were in a high state of digestion with only the outer skeleton remaining. The small size and low frequency of occurrence of these remains suggests that crustaceans were not targeted prey items and may have been secondarily ingested by Moroteuthis ingens from the stomachs of fish prey. 
Table 2. Prey species identified in the stomach contents of Moroteuthis ingens. $\mathrm{n}$ : total number of otoliths collected from stomach contents

\begin{tabular}{|lrcr|}
\hline Prey item & $\begin{array}{c}\text { Percentage } \\
\text { occurrence }\end{array}$ & $\begin{array}{c}\text { No. of otoliths } \\
(\mathrm{n}=424)\end{array}$ & $\begin{array}{c}\text { Percentage of } \\
\text { total otoliths }\end{array}$ \\
\hline Family Bathylagidae & & & \\
$\quad$ Bathylagus antarcticus & 19 & 19 & 5 \\
Family Myctophidae & & & \\
$\quad$ Electrona antarctica & 11 & 17 & 4 \\
E. carlsbergii & 6 & 5 & 1 \\
E. subaspera & 17 & 55 & 13 \\
Electrona sp. & 2 & 2 & 1 \\
Gymnoscopelus braueri & 19 & 43 & 5 \\
G. fraseri & 9 & 23 & 1 \\
G. hintonoides & 2 & 4 & 2 \\
G. nicholsi & 15 & 21 & 1 \\
G. piabilis & 9 & 10 & 4 \\
Gymnoscopelus sp. & 11 & 85 & 2 \\
Hintonia sp. & 2 & 2 & 9 \\
Krefftichthys anderssoni & 15 & 69 & \\
Protomyctophum bolini & 11 & 15 & \\
P. normanii & 6 & 10 & \\
Protomyctophum sp. & 21 & 40 & \\
Family Paralepididae & & & \\
$\quad$ Magnisudis prinosa & 4 & 4 & \\
Total fish & 96 & & \\
Beaks & 34 & & \\
Statoliths & 17 & & \\
Total squid & 47 & & \\
Hyperiid amphipods & & & \\
Hyperiella dilata & 2 & & \\
Solopes sp. & 2 & & \\
Gameriid amphipods & 9 & & \\
Unidentified copepods & & & \\
Total crustaceans & & & \\
& & & \\
& & & \\
& & & \\
\hline
\end{tabular}

sums of PUFA or saturated fatty acids (as a percentage of total fatty acids) between squid from Macquarie Island and those from Heard Island. However, the sum of monounsaturated fatty acids (MUFA) was significantly higher in mantle tissue from Heard Island than in that from Macquarie Island $(\mathrm{p}<0.02$; mean values $17.6 \pm 0.9$ and $15.4 \pm 1.4 \%$, respectively).

\section{Digestive gland}

Lipid class and fatty acid profiles of the DG were very different from those of mantle tissue. Total lipid content (percentage wet mass) was much higher in the DG than in the mantle, and was highly variable. Total DG lipid content in Macquarie Island animals ranged between $15.9 \%$ wet mass and $47.4 \%$ wet mass, with a mean value of $26.8 \pm 12.9 \%$ wet mass (Table 3). Total DG lipid content in Heard Island squid ranged between $33.5 \%$ wet mass and $56.7 \%$ wet mass, with a mean value of $41.7 \pm$ $8.5 \%$ wet mass (Table 3 ). TAG was the major lipid class, contributing 75.0 \pm $17.5 \%$ and $91.4 \pm 1.6 \%$ to total lipid in squid from Macquarie Island and from Heard Island, respectively (Table 4). Free fatty acids were moderately high,

\section{Lipids and fatty acids}

Mantle

Mantle tissue had a mean lipid content of $1.5 \pm 0.1 \%$ wet mass in Macquarie Island squid and similarly $1.5 \pm$ $0.1 \%$ in Heard Island animals (Table 3). The major lipid class in animals from both areas was phospholipid, which comprised 77 to $83 \%$ of total lipid (Table 4). Sterols, almost exclusively cholesterol (data not shown), and free fatty acids contributed $11.5 \pm 0.9$ and $9.9 \pm 4.0 \%$, respectively, to total lipid content in Heard Island animals. Sterols were the only other major lipid class in Macquarie Island squid and comprised $12.3 \pm 1.6 \%$ of total lipids.

The fatty acid profiles of mantle tissue were dominated by PUFA, which comprised over $50 \%$ of fatty acid content (Table 5). The main PUFA were eicosapentanoic acid (EPA; 20:5n3) and docosahexanoic acid (DHA; 22:6n3); no other PUFA were above $2.5 \%$. The saturated fatty acid 16:0 was also abundant $(26 \%)$. There were no significant differences in the comprising $11.7 \pm 6.9 \%$ of total lipids in Macquarie Island squid and $5.4 \pm 1.2 \%$ in Heard Island squid. High free fatty acid concentrations in the DG have been reported for several other squid species (Hayashi et al. 1985, Hayashi \& Yamamoto 1987b, Kawasaki et al. 1994, Hayashi 1996) and may be

Table 3. Total lipid content (\% wet mass) of the mantle and digestive gland tissue of Moroteuthis ingens from Macquarie and Heard islands, and of the stomach fluid of $M$. ingens from Heard Island

\begin{tabular}{|lc|}
\hline Sample & Total lipid content \\
\hline Mantle & \\
Macquarie Island & $1.5 \pm 0.1$ \\
Heard Island & $1.5 \pm 0.1$ \\
Digestive gland & \\
Macquarie Island & $26.8 \pm 12.9$ \\
Heard Island & $41.7 \pm 8.5$ \\
Stomach fluid & \\
Heard Island & $16.8 \pm 10.6$ \\
\hline
\end{tabular}


Table 4. Percentage lipid class (of total lipids) of the mantle and digestive gland of Moroteuthis ingens from Macquarie and Heard Islands, and stomach fluid of $M$. ingens from Heard Island. Mean values with standard deviations are given for mantle and digestive tissue, whereas minimum (min) and maximum (max) content of each lipid class is given for stomach fluid. DAGE: diacylglyceryl ethers; FFA: free fatty acids; PL: phospholipids; ST: sterols; TAG: triacylglycerol; WE: wax ester

\begin{tabular}{|c|c|c|c|c|c|}
\hline \multirow[t]{2}{*}{ Lipid class } & \multicolumn{2}{|c|}{ Mantle } & \multicolumn{2}{|c|}{ Digestive gland } & \multirow{2}{*}{$\begin{array}{c}\text { Stomach fluid } \\
\text { Heard Island }(\mathrm{n}=4) \\
\text { Min. Max. }\end{array}$} \\
\hline & $\begin{array}{l}\text { Macquarie Island } \\
\qquad(\mathrm{n}=6)\end{array}$ & $\begin{array}{l}\text { Heard Island } \\
\qquad(\mathrm{n}=6)\end{array}$ & $\begin{array}{l}\text { Macquarie Island } \\
\qquad(\mathrm{n}=5)\end{array}$ & $\begin{array}{l}\text { Heard Island } \\
\qquad(\mathrm{n}=6)\end{array}$ & \\
\hline WE & $0.0 \pm 0.0$ & $0.0 \pm 0.0$ & $2.0 \pm 0.9$ & $0.7 \pm 0.4$ & $0.0-53.8$ \\
\hline DAGE & $0.0 \pm 0.0$ & $0.0 \pm 0.0$ & $1.6 \pm 1.1$ & $0.4 \pm 0.5$ & $0.0-0.0$ \\
\hline TAG & $1.9 \pm 1.7$ & $1.9 \pm 0.6$ & $75.0 \pm 17.5$ & $91.4 \pm 1.6$ & $17.9-87.5$ \\
\hline FFA & $2.7 \pm 0.7$ & $9.9 \pm 4.0$ & $11.7 \pm 6.9$ & $5.4 \pm 1.2$ & $3.5-5.6$ \\
\hline ST & $12.3 \pm 1.6$ & $11.5 \pm 0.9$ & $3.9 \pm 3.1$ & $0.7 \pm 0.2$ & $0.2-0.8$ \\
\hline PL & $83.1 \pm 2.1$ & $76.7 \pm 4.3$ & $5.8 \pm 7.7$ & $1.6 \pm 0.5$ & $6.9-22.5$ \\
\hline
\end{tabular}

Table 5. Percentage fatty acids (of total fatty acids) of the mantle and digestive gland tissue of Moroteuthis ingens from Macquarie and Heard Islands, and of stomach fluid of $M$. ingens from Heard Island. Values are mean \pm SD. AA: arachidonic acid; DHA: docosahexaenoic acid; DPA: docosapentaenoic; EPA: eicosapentaenoic acid; MUFA: monounsaturated fatty acids; PUFA: polyunsaturated fatty acids; SAT: saturated fatty acid

\begin{tabular}{|c|c|c|c|c|c|}
\hline \multirow[t]{2}{*}{ Fatty acid } & \multicolumn{2}{|c|}{ Mantle } & \multicolumn{2}{|c|}{ Digestive Gland } & \multirow{2}{*}{$\begin{array}{l}\text { Stomach fluid } \\
\text { Heard Island } \\
\qquad(\mathrm{n}=4)\end{array}$} \\
\hline & $\begin{array}{l}\text { Macquarie Island } \\
\qquad(\mathrm{n}=6)\end{array}$ & $\begin{array}{l}\text { Heard Island } \\
\qquad(\mathrm{n}=6)\end{array}$ & $\begin{array}{l}\text { Macquarie Island } \\
\qquad(\mathrm{n}=5)\end{array}$ & $\begin{array}{l}\text { Heard Island } \\
\qquad(\mathrm{n}=6)\end{array}$ & \\
\hline $14: 0$ & $1.7 \pm 0.3$ & $1.8 \pm 0.3$ & $3.4 \pm 0.5$ & $3.5 \pm 0.3$ & $5.1 \pm 1.4$ \\
\hline $16: 0$ & $25.8 \pm 0.6$ & $25.7 \pm 0.6$ & $17.8 \pm 1.6$ & $15.8 \pm 0.7$ & $16.5 \pm 3.0$ \\
\hline $17: 0$ & $0.5 \pm 0.1$ & $0.4 \pm 0.0$ & $0.4 \pm 0.1$ & $0.3 \pm 0.1$ & $0.4 \pm 0.2$ \\
\hline $18: 0$ & $2.7 \pm 0.2$ & $2.3 \pm 0.1$ & $3.2 \pm 1.8$ & $3.3 \pm 0.2$ & $2.7 \pm 0.2$ \\
\hline $16: 1 \mathrm{n} 7$ & $0.8 \pm 0.1$ & $1.4 \pm 0.1$ & $5.0 \pm 1.2$ & $5.2 \pm 0.8$ & $7.9 \pm 2.0$ \\
\hline $18: 1 n 9$ & $3.7 \pm 0.2$ & $4.6 \pm 0.4$ & $27.3 \pm 4.2$ & $20.5 \pm 1.2$ & $23.4 \pm 3.0$ \\
\hline $18: 1 \mathrm{n} 7$ & $1.9 \pm 0.2$ & $2.0 \pm 0.1$ & $5.1 \pm 1.2$ & $3.6 \pm 0.3$ & $4.6 \pm 0.1$ \\
\hline $18: 1 \mathrm{n} 5$ & $0.4 \pm 0.1$ & $0.4 \pm 0.0$ & $0.7 \pm 0.1$ & $0.6 \pm 0.0$ & $0.6 \pm 0.2$ \\
\hline 20:1n9 & $5.5 \pm 0.9$ & $5.5 \pm 0.1$ & $8.8 \pm 2.5$ & $9.2 \pm 1.5$ & $6.4 \pm 2.1$ \\
\hline $20: 1 \ln 7$ & $0.1 \pm 0.0$ & $0.3 \pm 0.5$ & $0.6 \pm 0.1$ & $0.6 \pm 0.1$ & $0.4 \pm 0.1$ \\
\hline $22: 1 n 11$ & $0.3 \pm 0.1$ & $0.5 \pm 0.1$ & $3.6 \pm 0.4$ & $5.0 \pm 1.1$ & $2.4 \pm 1.0$ \\
\hline $22: 1 n 9$ & $1.4 \pm 0.2$ & $1.3 \pm 0.1$ & $1.9 \pm 0.2$ & $2.2 \pm 0.3$ & $1.7 \pm 0.4$ \\
\hline $22: 1 \mathrm{n} 7$ & $0.1 \pm 0.0$ & $0.1 \pm 0.0$ & $0.3 \pm 0.0$ & $0.5 \pm 0.3$ & $0.2 \pm 0.1$ \\
\hline $24: 1 \mathrm{n} 11$ & $0.1 \pm 0.0$ & $0.2 \pm 0.0$ & $0.8 \pm 0.2$ & $1.3 \pm 0.2$ & $0.8 \pm 0.3$ \\
\hline $24: 1 \mathrm{n} 9$ & $0.3 \pm 0.1$ & $0.3 \pm 0.0$ & $1.0 \pm 0.3$ & $1.4 \pm 0.2$ & $1.0 \pm 0.2$ \\
\hline c16 PUFA & $0.0 \pm 0.0$ & $0.0 \pm 0.0$ & $0.5 \pm 0.1$ & $3.3 \pm 2.3$ & $2.0 \pm 3.0$ \\
\hline $18: 4 \mathrm{n} 3$ & $0.0 \pm 0.0$ & $0.0 \pm 0.0$ & $0.4 \pm 0.2$ & $0.5 \pm 0.1$ & $0.9 \pm 0.4$ \\
\hline $18: 2 \mathrm{n} 6$ & $0.2 \pm 0.0$ & $0.2 \pm 0.0$ & $1.3 \pm 0.2$ & $0.9 \pm 0.3$ & $1.2 \pm 0.2$ \\
\hline $20: 4 n 6$ ( AA) & $2.1 \pm 0.1$ & $1.3 \pm 0.2$ & $0.7 \pm 0.3$ & $0.6 \pm 0.1$ & $0.5 \pm 0.1$ \\
\hline 20:5n3 (EPA) & $13.6 \pm 0.4$ & $14.7 \pm 0.2$ & $4.4 \pm 1.9$ & $7.9 \pm 1.2$ & $9.0 \pm 3.7$ \\
\hline $20: 4 \mathrm{n} 3$ & $0.1 \pm 0.0$ & $0.1 \pm 0.0$ & $0.5 \pm 0.1$ & $0.6 \pm 0.0$ & $0.6 \pm 0.1$ \\
\hline $20: 2 \mathrm{n} 6$ & $0.5 \pm 0.1$ & $0.4 \pm 0.0$ & $0.6 \pm 0.6$ & $0.3 \pm 0.0$ & $0.2 \pm 0.1$ \\
\hline $22: 5 n 6$ & $0.2 \pm 0.1$ & $0.1 \pm 0.0$ & $0.6 \pm 0.2$ & $0.2 \pm 0.1$ & $0.0 \pm 0.0$ \\
\hline 22:6n3 (DHA) & $35.2 \pm 1.3$ & $33.9 \pm 0.5$ & $6.9 \pm 4.2$ & $9.1 \pm 0.9$ & $7.7 \pm 0.9$ \\
\hline $22: 5 n 3$ (DPA) & $0.5 \pm 0.1$ & $0.5 \pm 0.0$ & $0.6 \pm 0.2$ & $0.9 \pm 0.1$ & $0.9 \pm 0.2$ \\
\hline Sum SAT & $31.2 \pm 0.7$ & $30.9 \pm 0.5$ & $25.4 \pm 1.4$ & $23.4 \pm 1.1$ & $25.7 \pm 2.3$ \\
\hline Sum MUFA & $15.5 \pm 1.4$ & $17.6 \pm 0.9$ & $56.6 \pm 6.9$ & $51.1 \pm 1.9$ & $50.5 \pm 4.6$ \\
\hline Sum PUFA & $53.1 \pm 1.6$ & $51.5 \pm 0.5$ & $17.3 \pm 7.0$ & $25.0 \pm 1.8$ & $23.8 \pm 4.6$ \\
\hline
\end{tabular}

largely due to the enzymatic activity of the DG rather than to being products of storage.

Major fatty acids in the DG were 16:0, 18:1n9 and 20:1n9 (Table 5). MUFA were the major class of fatty acid. There were no significant differences in the sums of MUFA (as a percentage of total fatty acids) between DG from Macquarie Island and those from Heard Island. The sum of saturated fatty acid was significantly higher in DG tissue from Macquarie Island than in that from Heard Island $(p<0.04$, mean values $25.4 \pm$ 
1.4 and $23.4 \pm 1.1 \%$, respectively). The difference in the sum of PUFA between Macquarie and Heard islands was approaching significance $(\mathrm{p}<0.075$, mean values $17.3 \pm 0.7 \%$ and $25.0 \pm 1.8 \%$, respectively).

\section{Stomach fluid}

Total lipid content was highly variable among individual squid, with a minimum content of $4.8 \%$ wet mass and a maximum of $28.5 \%$ wet mass. The mean lipid content was $16.8 \pm 10.6 \%$ wet mass (Table 3 ). The proportions of lipid classes were also variable among individuals. Major lipid classes were TAG and wax ester; 3 stomach fluid samples contained large amounts of TAG (81.7 to $87.5 \%$ of total lipid), whereas the fourth was rich in wax ester (53.8\% of total lipid) (Table 4 ). Interestingly, however, there was relatively little variation in the fatty acid profiles among individuals despite these differences in lipid class content. Fatty acid profiles are dominated by MUFA with 16:0 and 18:1n9 again being major components. EPA and DHA concentrations were also relatively high (Table 5).

\section{Comparison with prey}

The fatty acid profiles of mantle and DG tissue of Moroteuthis ingens from Macquarie and Heard islands, and stomach fluid from Heard Island squid have been compared with previously published values of certain myctophid species using cluster analysis and MDS (Fig. 3). Lipid data are not available for many species of myctophid in the Southern Ocean, including some species listed in Table 2. However, lipid data are available for Electrona antarctica collected from Eastern Antarctica (Phleger et al. 1997), Gymnoscopelus braueri, G. opisthopterus, G. nicholsi, E. carlsbergii and Krefftichthys anderssoni collected from Elephant Island (Phleger et al. 1999), and G. piabilis and Protomyctophum bolini collected from the Crozet Archipelago (Raclot et al. 1998). In addition, comparisons have been made with 4 adult specimens of the Antarctic krill Euphausia superba from Elephant Island (M. M. Nelson pers. comm.), which is often cited to be an important prey item of squid in the Southern Ocean (Nemoto et al. 1985). These comparisons were made using a restricted selection of fatty acids, as governed by those
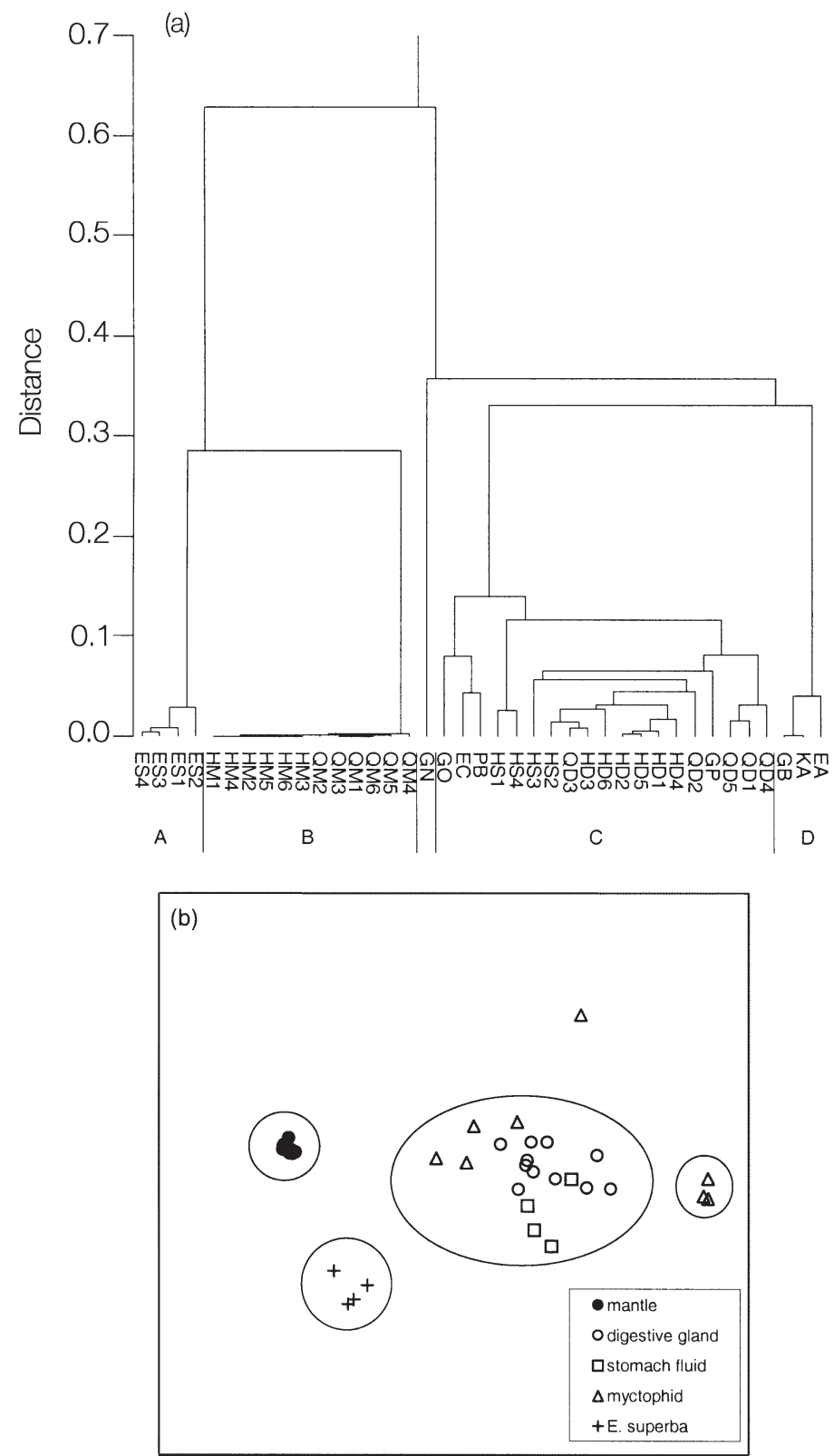

Fig. 3. (a) Dendrogram of cluster analysis comparing mantle and digestive gland tissue and stomach fluid of Moroteuthis ingens, myctophid species and Euphausia superba, using a suite of fatty acids. ES: Euphausia superba; HM: Heard Island mantle; QM: Macquarie Island mantle; GN: Gymnoscopelus nicholsi; GO: G. opisthopterus; EC: Electrona carlsbergii; PB: Protomyctophum bolini; HS: Heard Island stomach fluid; QD: Macquarie Island digestive gland; HD: Heard Island digestive gland; GP: G. piabilis; GB: G. braueri; KA: Krefftichthys anderssoni; EA: E. antarctica. (b) Scatterplot of multidimensional scaling (MDS) for data compared in cluster analysis (a); Stress $=0.033$, proportion of variance $=0.996$. Cluster groups identified in (a) are superimposed. Axis scales are arbitrary in non-metric MDS and are therefore omitted

suites available in the literature. This selection comprised 14:0, 16:0. 18:0. 16:1n7, 18:1n9, 18:1n7, 20:1n9, 22:1n11, 24:1n11, 18:2n6, EPA and DHA. 
Four main groups were defined at a distance of 0.29 in the cluster analysis, with 1 Gymnoscopelus nicholsi outlier (Fig. 3a). Group A comprised Euphausia superba, and Group B contained mantle tissue. Four myctophid species were clustered in Group C together with the DG tissue and stomach fluid, and Group D comprised the remaining 3 myctophid species. Good separation between these groups was also represented in a scatterplot of MDS (Fig. 3b).

\section{DISCUSSION}

\section{Diet of Moroteuthis ingens-stomach content analyses}

Stomach content analyses show that myctophid fish were the most common prey item by percentage occurrence in the diet of Moroteuthis ingens at Macquarie and Heard Islands. Other species of fish such as Bathylagus antarcticus were also commonly consumed. Only 4 stomachs were available from Heard Island squid, and consequently it was not feasible to analyse the sample sets separately and look for differences in the occurrence of prey frequency. While many species of fish and other pelagic organisms have a circumpolar distribution in the Southern Ocean, Macquarie and Heard Islands are found on opposite sides of the Antarctic Polar Front, which acts as a biological barrier to many organisms. Therefore, the composition of the diet is likely to differ between these 2 areas.

Myctophid fish were also important in the diet of Moroteuthis ingens collected from New Zealand waters (Jackson et al. 1998b), although fewer species were identified from the stomach contents of the New Zealand animals. Several other species of teleost were common prey items of the New Zealand squid that were not identified in the Macquarie and Heard Island squid. Gymnoscopelus sp. and Electrona sp. were the only ones identified in New Zealand stomachs that were identified in Macquarie and Heard stomachs. Therefore, it appears that the diet of $M$. ingens is markedly different at the northern limits of its distribution from that at its sub-Antarctic habitat.

\section{Lipids of Moroteuthis ingens and comparison with prey items}

No stomachs from Macquarie Island squid had been suitably processed to facilitate fatty acid analysis of fluid portions. However, the fluid from all 4 stomachs collected from Heard Island were analysed and were found to be variable in lipid composition. Three stomachs contained large amounts of TAG while 1 stomach was rich in wax ester (Table 4). The majority of myctophids accumulate TAG as their major storage lipid, including Electrona carlsbergii, Gymnoscopelus nicholsi and G. opisthopterus (the latter were not identified from Moroteuthis ingens stomach contents in this study). A smaller number of species store large amounts of wax ester with only trace amounts of TAG (Saito \& Murata 1998, Phleger et al. 1999). E. antarctica, G. braueri and Krefftichthys anderssoni are species rich in wax ester. Therefore, high TAG and wax ester concentrations in the stomach fluid may be accounted for by a myctophid diet.

The DG tissue grouped with stomach fluid from Heard Island squid in both cluster analysis and MDS (Fig. 3). Both the DG and the stomach fluid are characterised by high MUFA content, and the major lipid component of the DG is TAG. Overall these findings suggest that there is little modification of fatty acids (for example desaturation) in the transport of lipids from the stomach to the DG. The DG of Moroteuthis ingens also groups with the TAG-rich myctophids Gymnoscopelus opisthopterus and Electrona carlsbergii, and G. piabilis and Protomyctophum bolini, for which lipid class data are not available, suggesting that there are strong correlations between the fatty acid profile of the DG and these prey items. Conversely, Euphausia superba did not group with DG tissue or any other group. Similarly, G. nicholsi was an outlier in both cluster analysis and MDS, indicating that the fatty acid profile of neither of these 2 species is reflected in the mantle or DG tissue of $M$. ingens.

Three wax ester-rich myctophid species (Gymnoscopelus braueri, Krefftichthys anderssoni and Electrona antarctica) grouped together independent of any other tissue or prey type (Fig. 3). The fatty acid profile of these species is less similar to that of the DG than it is to that of other myctophid species, and suggests that these prey items make lesser contributions to the diet of Moroteuthis ingens. These findings somewhat contradict those of stomach contents analyses, as $G$. braueri and $K$. anderssoni were 2 of the most common prey items identified (the former by percentage frequency occurrence, the latter by percentage of total otoliths). However, many of the Gymnoscopelus otoliths are difficult to identify to species level, particularly when eroded; therefore, the percentage frequency occurrence of $G$. braueri in the diet of $M$. ingens may be over-estimated. The use of fatty acids as dietary tracers may expose sources of error when quantifying important prey items from stomach contents, particularly when hard body parts are eroded and cannot be reliably used to estimate standard length and mass of prey, as in this study, or when identification can be difficult. In addition, the DG fatty acid 
profile may have the capacity to highlight a group of prey species that are commonly included in the diet over an extended time frame, in contrast to the 'instantaneous snapshot' of the diet provided by stomach contents analyses. Alternatively, the representation of species with more unusual lipid profiles (such as wax ester-rich myctophids) may be obscured in the fatty acid profile of the DG, thus limiting its usefulness as an indicator of important prey groups. However, fatty alcohols were found only in small amounts in the DG (data not shown), indicating that the diet of these squid was low in wax ester and that TAG-rich species are more commonly consumed.

The mantle tissue of Moroteuthis ingens contained low lipid content, which was characterised by high concentrations of phospholipids and PUFA. PUFA are often associated with structural lipids, in particular phospholipids (Sargent 1976); therefore, the role of lipid in the mantle of $M$. ingens is likely to be largely structural. These data agree will with those in the literature, where PUFA dominate the flesh tissue of other squid species such as Illex illecebrosus (Jangaard 1965), Loligo beka (Ha 1982), L. vulgaris (de Koning 1993), Gonatopsis borealis (Hayashi 1989), Berryteuthis magister (Hayashi \& Yamamoto 1987a), G. makko (Hayashi et al. 1990) and Moroteuthis robusta (Hayashi et al. 1990).

The origin of PUFA in the mantle tissue of squids is unclear. PUFA may be selectively absorbed from the diet and transferred to the mantle without further modification, or, alternatively, squid may have some metabolic capacity for chain elongation and desaturation of dietary fatty acids transported to the mantle. We propose that the lipid in squid mantle tissue fulfils specific structural requirements, and because of selective uptake or modification of fatty acids, the profile of the mantle is less likely to reflect that of important prey items. This is illustrated in Fig. 3, where mantle tissue is well separated from potential prey items, the DG and stomach fluid, where dietary fatty acids are likely to be stored or accumulated.

We are unable to identify individual prey species from the fatty acid profile of either the mantle or DG of Moroteuthis ingens. It will be important to verify and quantify the influence of diet on the lipid composition of the DG of squid in the future, to extend the usefulness of DG fatty acids as dietary tracers. In the first instance, captive-feeding trials, where squid are kept on a restricted diet of live prey, may potentially achieve this. After a period of time, lipid uptake from the diet may be reflected in the lipid composition of the DG and perhaps in other tissues such as the mantle. Captive feeding trials are more likely to be successful with coastal squid species, rather than oceanic oegopsids such as Moroteuthis ingens.

\section{Implications for squid ecology in the Southern Ocean}

Myctophids are known to be the major prey item of other squid species in the Southern Ocean, such as the ommastrephid Martialia hyadesi. After studying the stomach contents of this species collected from the Atlantic Sector of the Southern Ocean, Rodhouse et al. (1992) proposed that a previously unrecognised food chain, copepod-myctophid-M. hyadesi-higher predator, may be operating in the Antarctic oceanic ecosystem that is largely independent of the keystone species, Antarctic krill Euphausia superba. On the basis of the stomach contents and fatty acid profiles of Moroteuthis ingens, it appears that a similar food chain is important on the continental slopes near Macquarie and Heard Islands; that is, copepod-myctophid- $M$. ingens-higher predator. $M$. ingens has also been reported to feed on mesopelagic fish in New Zealand waters (Jackson et al. 1998b). Squid are thought to have replaced fish as the major nektonic predators in the epipelagic zone of the Southern Ocean (Rodhouse \& White 1995). Therefore, if other squid species also depend heavily on myctophids and mesopelagic fish, the copepod-myctophid-squid-higher predator food chain may be one of the most widespread and overlooked food chains in the Southern Ocean.

Many dietary studies of squid are hampered by the possibility that squid have been feeding in sampling gear, and consequently that stomach contents do not represent natural feeding behaviour. Our study was not likely to be affected by this source of bias, as all stomach contents were in a moderate to high state of digestion. This indicates that Moroteuthis ingens had not fed recently before capture. The similarities between the DG lipid composition and that of the stomach fluid also suggests that, in this case, the range of prey items identified from stomach contents provided a good representation of natural feeding behaviour.

Squid, including Moroteuthis ingens, are often described as krill feeders in the Southern Ocean (Nemoto et al. 1985) based on stomach contents analyses. However, many squid have been collected in surface waters $(0$ to $200 \mathrm{~m}$ ) in nets designed to catch Euphausia superba (Nemoto et al. 1988), which is likely to have biased dietary studies and hence our perception of the feeding ecology of squid in the Southern Ocean. On the basis of a study of feeding of the sperm whale Physeter macrocephalus on squid, Nemoto et al. (1988) suggest that there are several unidentified links in the food web between E. superba, squid and sperm whales. The thickness of sperm whale blubber was not found to increase seasonally in Antarctic waters relative to increased zooplankton 
production, in contrast to the blubber thickness of baleen whales. The fatty acid profile of E. superba showed no similarities to those of $M$. ingens in this study, although this was expected as the distribution of E. superba does not extend as far north as Macquarie and Heard Islands, and it was not identified in stomach contents. However, it should be possible to collect squid, such as other species of onychoteuthids, from Antarctic waters where E. superba is distributed and determine from stomach content analyses and DG lipid content whether E. superba comprises a major component of the diet, or whether it is only taken opportunistically.

\section{CONCLUSIONS}

The stomach contents of Moroteuthis ingens collected from Macquarie and Heard Islands show that this squid depends heavily on teleost fish in the subAntarctic Southern Ocean and, of these, myctophid species are the most common group consumed. Using a combination of cluster analysis and MDS, the fatty acid profile of the DG of $M$. ingens was shown to support the findings from stomach contents analyses. The use of DG fatty acids as tracers has potential applications for future dietary studies of squid, particularly where the likelihood that squid have been feeding in sampling gear is high and thus error has been introduced to stomach contents analyses.

Acknowledgements. K. Phillips is a recipient of a Tasmanian Strategic Research Scholarship. We thank J. Finn and B. McGrath for helping with squid dissections, D. Williams (Australian Antarctic Division) for his assistance with otolith identification, and G. Hosie and J. Kitchener (both of the Australian Antarctic Division) for identifying crustaceans. D. Holdsworth managed the CSIRO GC-MS facility, and M. Nelson kindly provided Euphausia superba lipid data. We would also like to thank the crew and scientific observers on board the 'Austral Leader' and 'Southern Champion', and 3 anonymous referees who provided useful comments on the manuscript. This work is part of an ARC large grant (grant no. A19933031).

\section{LITERATURE CITED}

Ackman RG (1980) Fish lipids. Part 1. In: Connell JJ (ed) Advances in fish science and technology. Fishing News Books Ltd, Farnham, p 86-103

Ballantyne JS, Hochachka PW, Mommsen TP (1981) Studies on the metabolism of the migratory squid, Loligo opalescens: enzymes of tissues and heart mitochondria. Mar Biol Lett 2:75-85

Bligh EG, Dyer WJ (1959) A rapid method of total lipid extraction and purification. Can J Biochem Physiol 37:911-917

Clarke MR, Goodall N (1994) Cephalopods in the diets of three odontocete cetacean species stranded at Tierra del
Fuego, Globicephala melaena (Traill, 1809), Hyperoodon planifrons (Flower, 1882) and Cephalorhynchus commersonii (Lacepede, 1804). Antarct Sci 6:149-154

Clarke M, Roeleveld MAC (1998) Cephalopods in the diet of sperm whales caught commercially off Durban, South Africa. S Afr J Mar Sci 20:41-45

Clarke MR, Denton EJ, Gilpin-Brown JB (1979) On the use of ammonium for buoyancy in squids. J Mar Biol Assoc UK 59:259-276

Cherel Y, Ridoux V, Rodhouse PG (1996) Fish and squid in the diet of king penguin chicks, Aptenodytes patagonicus, during winter at sub-antarctic Crozet Islands. Mar Biol 126:559-579

Dawe EG, Dalley EL, Lidster WW (1997) Fish prey spectrum of short finned squid (Illex illecebrosus) at Newfoundland. Can J Fish Aquat Sci 54:200-208

de Koning AJ (1993) Phospholipids of marine origin - the squid (Loligo vulgaris). J Sci Food Agric 61:129-132

Green K, Burton HR (1993) Comparison of the stomach contents of Southern Elephant Seals Mirounga leonina, at Macquarie and Heard Islands. Mar Mamm Sci 9:10-22

Ha BS (1982) Studies on the lipid of aquatic products (part 4): On the flesh lipid composition of cephalopods. Bull Korean Fish Soc 15:59-73

Hayashi K (1989) Occurrence of diacyl glyceryl ethers in liver lipids of gonatid squid Gonatopsis borealis. Nippon Suisan Gakkaishi 55:1383-1387

Hayashi K (1996) Composition and distribution of lipids in different tissues of the Arrow Squid Loligo bleekeri. Fish Sci 62:84-87

Hayashi K, Yamamoto S (1987a) Distribution of diacyl glyceryl ethers in the different tissues and stomach contents of gonatid squid Berryteuthis magister. Nippon Suisan Gakkaishi 53:1057-1063

Hayashi K, Yamamoto S (1987b) Content and composition of alkyl glyceryl ethers in liver of gonatid squid Berryteuthis magister from the Northwestern Pacific. Nippon Suisan Gakkaishi 53:137-140

Hayashi K, Okawa Y, Kawasaki K (1985) Liver lipids of gonatid squid Berryteuthis magister: a rich source of alkyl glyceryl ethers. Bull Jpn Soc Sci Fish 51:1523-1526

Hayashi K, Kishimura H, Sakurai Y (1990) Level and composition of diacyl glyceryl ethers in the different tissues and stomach contents of giant squid Moroteuthis robusta. Nippon Suisan Gakkaishi 56:1635-1639

Jackson GD (1993) Growth zones within the statolith microstructure of the deepwater squid Moroteuthis ingens (Cephalopoda: Onychoteuthidae): evidence for a habitat shift? Can J Fish Aquat Sci 50:2366-2374

Jackson GD, George MJA, Buxton NG (1998a) Distribution and abundance of the squid Moroteuthis ingens (Cephalopoda: Onychoteuthidae) in the Falkland Islands region of the South Atlantic. Polar Biol 20:161-169

Jackson GD, McKinnon JF, Lalas C, Ardern R, Buxton NG (1998b) Food spectrum of the deepwater squid Moroteuthis ingens (Cephalopoda: Onychoteuthidae) in New Zealand waters. Polar Biol 20:56-65

Jackson GD, Buxton NG, George MJA (2000) The diet of the southern Opah Lampris immaculatus on the Patagonian Shelf; the significance of the squid Moroteuthis ingens and anthropogenic plastic. Mar Ecol Prog Ser 206:261-271

Jangaard PM, Ackman RG (1965) Lipids and component fatty acids of the Newfoundland squid Illex illecebrosus (Le Sueur). J Fish Res Board Can 22:131-137

Kawasaki K, Ooizumi T, Hayashi S, Hayashi K (1994) Lipid class and fatty acid composition of liver of firefly squid Watasenia scintillans. Nippon Suisan Gakkaishi 60:247-251 
Kear AJ (1992) The diet of Antarctic squid: comparison of conventional and serological gut contents analyses. J Exp Mar Biol Ecol 156:161-178

Lipinski MR (1979) Universal maturity scale for the commercially important squids. The results of maturity classification of the Illex illecebrosus (Le Sueur, 1821) population for the years 1973-1977. Res Doc Int Comm Northwest Atl Fish (ICNAF) 79/II/38 (Serial No. 5364) p 1-490

Lipinski MR (1987) Food and feeding of Loligo vulgaris reynaudii from St Francis Bay, South Africa. S Afr J Mar Sci 5:557-564

Lordan C, Burnell GM, Cross TF (1998) The diet and ecological importance of Illex coindetii and Todaropsis eblanae (Cephalopoda: Ommastrephidae) in Irish waters. S Afr J Mar Sci 20:153-163

Mommsen TP, Hochachka PW (1981) Respiratory and enzymatic properties of squid heart mitochondria. Eur $\mathrm{J}$ Biochem 120:345-250

Nemoto T, Okiyama M, Takahashi M (1985) Aspects of the roles of squid in food chains of marine Antarctic ecosystems. In: Siegfried WR, Condy PR, Laws RM (eds) Antarctic nutrient cycles and food webs. Springer-Verlag, Berlin, p 415-420

Nemoto T, Okiyama M, Iwasaki N, Kikuch T (1988) Squid as predators on krill (Euphausia superba) and prey for sperm whales in the Southern Ocean. In: Sahrhage D (ed) Antarctic Ocean and resources variability. Springer-Verlag, Berlin, p 292-296

Nichols PD, Nichols DS, Bakes MJ (1994) Developments with marine oil products in Australia. A.O.C.S Int News Fats Oils Relat Mater 5:254-261

Phleger CF, Nichols PD, Virtue P (1997) The lipid, fatty acid and fatty alcohol composition of the myctophid fish Electrona antarctica: high levels of wax esters and food-chain implications. Antarct Sci 9:258-265

Editorial responsibility: Otto Kinne (Editor),

Oldendorf/Luhe, Germany
Phleger CF, Nelson MM, Mooney BD, Nichols PD (1999) Wax esters versus triacylglycerols in myctophid fishes from the Southern Ocean. Antarct Sci 11:436-444

Raclot T, Groscolas R, Cherel Y (1998) Fatty acid evidence for the importance of myctophid fishes in the diet of king penguins, Martialia patagonicus. Mar Biol 132:523-533

Rodhouse RG, White MG (1995) Cephalopods occupy the ecological niche of epipelagic fish in the Antarctic Polar Frontal Zone. Biol Bull 189:77-80

Rodhouse PG, Nigmatullin CM (1996) Role as consumers. Philos Trans R Soc Lond B Biol Sci 351:1003-1022

Rodhouse PG, White MG, Jones MRR (1992) Trophic relations of the cephalopod Martialia hyadesi (Teuthoidea: Ommastrphidae) at the Antarctic Polar Front, Scotia Sea. Mar Biol 114:415-421

Saito H, Murata M (1998) Origin of the monoene fats in the lipid of midwater fishes: relationship between the lipids of myctophids and those of their prey. Mar Ecol Prog Ser 168:21-33

Sargent JR (1976) The structure, metabolism and function of lipids in marine organisms. In: Malins DC, Sargent JR (eds) Biochemical and biophysical perspectives in marine biology, Vol 3. Academic Press, London, p 149-212

Semmens JM (1998) An examination of the role of the digestive gland of two loliginid squids, with respect to lipid: storage or excretion? Proc R Soc Lond Ser B Biol Sci 265:1685-1690

Vonk HJ (1962) Emulgators in the digestive fluids of invertebrates. Arch Int Physiol Biochim 70:67-85

Williams R, McEldowney A (1990) A guide to the fish otoliths from waters off the Australian Antarctic Territory, Heard and Macquarie Islands. ANARE Res Notes 75:173

Zuev GV, Nigmatullin CM, Nikolsky VN (1985) Nektonic oceanic squids (genus Stenoteuthis). Agropromizdat, Moscow (in Russian)

Submitted: September 15, 1999; Accepted: February 15, 2001 Proofs received from author(s): May 10, 2001 